\title{
Applications of the CRISPR/Cas9 System for Rice Grain Quality Improvement: Perspectives and Opportunities
}

\author{
Sajid Fiaz $^{1, *(\mathbb{D}}$, Shakeel Ahmad ${ }^{1}\left(\mathbb{D}\right.$, Mehmood Ali Noor $^{2}{ }^{(0)}$, Xiukang Wang ${ }^{3, *(\mathbb{D}}$, Afifa Younas ${ }^{4}$, \\ Aamir Riaz ${ }^{1}$, Adeel Riaz ${ }^{5}$ (i) and Fahad Ali ${ }^{1}$ \\ 1 State Key Laboratory of Rice Biology, China National Rice Research Institute, Hangzhou 310006, China; \\ shakeelpbg@gmail.com (S.A.); aamirriaz33@gmail.com (A.R.); fahadali.pbg@hotmail.com (F.A.) \\ 2 Institute of Crop Sciences, Chinese Academy of Agricultural Sciences, Key Laboratory of Crop Physiology \\ and Ecology, Ministry of Agriculture, Beijing 100081, China; mehmood2017@gmail.com \\ 3 College of Life Sciences, Yan'an University, Yan'an 716000, Shaanxi, China \\ 4 Department of Botany, Lahore College for Women University, Lahore 54000, Pakistan; \\ afifa_younas@hotmail.com \\ 5 Biotechnology Research Institute, Chinese Academy of Agricultural Sciences, Beijing 100081, China; \\ adeelpopy@yahoo.com \\ * Correspondence: sajidfiaz50@yahoo.com (S.F.); wangxiukang@126.com (X.W.); \\ Tel.: +86-132-2142-1682 (S.F.); +86-571-6337-0221 (X.W.)
}

Received: 22 December 2018; Accepted: 15 February 2019; Published: 19 February 2019

\begin{abstract}
Grain quality improvement is a key target for rice breeders, along with yield. It is a multigenic trait that is simultaneously influenced by many factors. Over the past few decades, breeding for semi-dwarf cultivars and hybrids has significantly contributed to the attainment of high yield demands but reduced grain quality, which thus needs the attention of researchers. The availability of rice genome sequences has facilitated gene discovery, targeted mutagenesis, and revealed functional aspects of rice grain quality attributes. Some success has been achieved through the application of molecular markers to understand the genetic mechanisms for better rice grain quality; however, researchers have opted for novel strategies. Genomic alteration employing genome editing technologies (GETs) like clustered regularly interspaced short palindromic repeats (CRISPR)/CRISPR-associated protein 9 (Cas9) for reverse genetics has opened new avenues of research in the life sciences, including for rice grain quality improvement. Currently, CRISPR/Cas9 technology is widely used by researchers for genome editing to achieve the desired biological objectives, because of its simple targeting. Over the past few years many genes that are related to various aspects of rice grain quality have been successfully edited via CRISPR/Cas9 technology. Interestingly, studies on functional genomics at larger scales have become possible because of the availability of GETs. In this review, we discuss the progress made in rice by employing the CRISPR/Cas9 editing system and its eminent applications. We also elaborate possible future avenues of research with this system, and our understanding regarding the biological mechanism of rice grain quality improvement.
\end{abstract}

Keywords: functional genomics; Oryza sativa L. molecular markers; reverse genetics; CRISPR/Cas9

\section{Introduction}

Rice (Oryza sativa L.) feeds more than 3.5 billion people worldwide [1]. Rice grain quality preferences differ between geographical regions and/or ethnic groups [2]. The prime characteristics affecting quality are cooking and eating parameters, phytochemicals, and micronutrients [3]. 
The assessment of grain quality is a laborious and time-consuming task that not only requires large amounts of samples at early stages of breeding, but also adherence to standard protocols [4]. Understanding the molecular basis of grain quality has been a prime objective of past quality improvement research. The fine-mapping and cloning of quantitative trait loci (QTLs) for grain quality improvement have received more attention recently, because of its large economic value and consumer preference [5]. Several regulatory and structural genes, chemical pathways, and regulatory networks involved in grain quality, have been identified using various approaches. In the current scenario, conventional mutational breeding techniques, i.e., ethyl methanesulfonate and X-rays, have multiple limitations, and new techniques, i.e., CRISPR/Cas9 are highly desirable for achieving the goal of rice grain quality improvement with more precision and higher efficiency [6].

The functions of various components of the rice genome ultimately enable the production of higher yielding varieties with better quality rice grains $[7,8]$. Currently, CRISPR/Cas9 is a widely adopted genome editing technology (GET) because of its simplicity, efficiency, and versatility [9]. The target specificity in CRISPR-Cas9 system is the most reliable, as target sites are recognized by Watson and Crick model, and off-target sites are identified through sequence analysis [10]. CRISPR/Cas9 cleaves foreign DNA via two components, Cas9 and single guide RNA (sgRNA). Cas9 is a DNA endonuclease that can be derived from different bacteria, such as Brevibacillus laterosporus [11], Staphylococcus aureus [12], Streptococcus pyogenes [13], Streptococcus thermophilus [14], and Streptococcus pyogenes is the most widely used for Cas9 isolation. Cas9 contains two domains, i.e., the HNH domain and the RucV-like domain. The HNH domain cuts the complementary strand of CRISPR RNA (crRNA), while the RucV-like domain cleaves the opposite strand of the double-stranded DNA. The sgRNA is a synthetic RNA with a length of about $100 \mathrm{nt}$. Its $5^{\prime}$-end has a 20-nt sequence that acts as a guide sequence to identify the target sequence accompanied by a protospacer adjacent motif (PAM) sequence, which is often the consensus NGG (N, any nucleotide; G, guanine). The loop structure at the 3 '-end of the sgRNA can anchor the target sequence by the guide sequence and form a complex with Cas9, which cleaves the double stranded DNA and forms a double-strand break (DSB) at this site. Once a DSB is generated, nonhomologous end-joining (NHEJ) or homology-directed repair (HDR) DNA repair mechanisms are initiated. A DSB is usually repaired by NHEJ in most situations, and it is a simple way to create mismatches and gene insertion/deletions (indel), leading to gene knockout. When an oligo-template is present, HDR induces specific gene replacement or foreign DNA knock-ins $[15,16]$. These processes are all ways in which CRISPR/Cas9 can efficiently edit the genome of diverse organisms, including humans, animals and plants (Figure 1).

Recent reviews have described the genetics and biotechnologies [17], integration of knowledge from omics-based studies [18], and methods for utilizing genome editing, particularly CRISPR/Cas9 for improving rice grain quality $[19,20]$. Scientists equipped with CRISPR expertise have contributed by disseminating relevant information to CRISPR newcomers, in contrast to the proprietary nature of zinc-finger nucleases. In addition, several online platforms are now available to assist researchers with all concerns relating to CRISPR [21-26]. Based on these developments, we provide a non-comprehensive review with special emphasis on the applications of the CRISPR/Cas9 system for the development of rice varieties with better grain quality. 


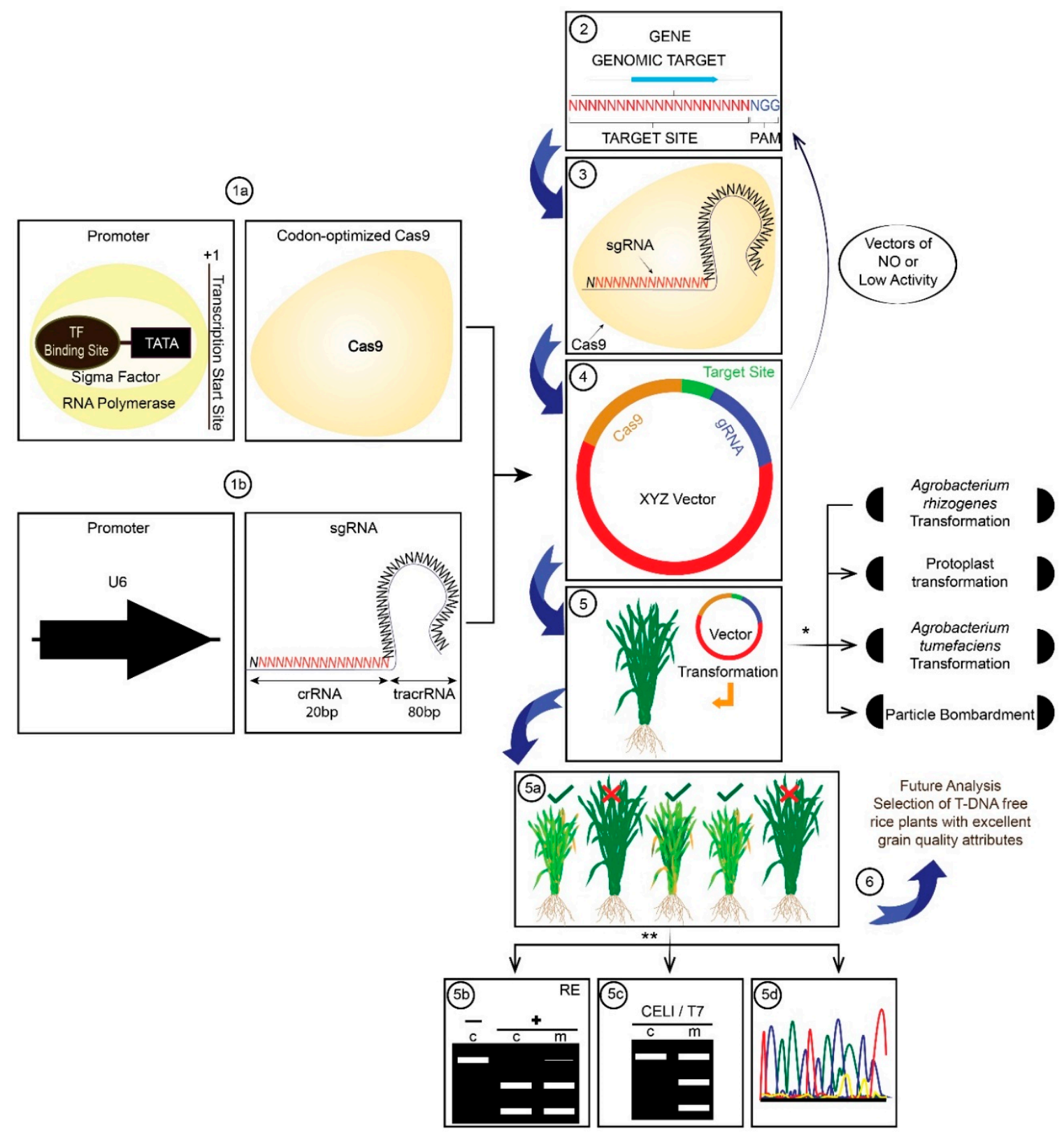

Figure 1. Basic flow chart of the CRISPR/Cas9 genome editing system. The engineered CRISPR/Cas9 system consist of two components; (1a) the Cas9 endonuclease and, (1) b a single-guide RNA (sgRNA). “The sgRNA contains a spacer sequence followed by 79 nt of an artificially fused tracrRNA and crRNA sequence", (2) The spacer sequence is typically $20 \mathrm{nt}$ in length, and specifically binds to the target DNA sequence containing a 5'-NGG-3' PAM motif at the 3' end, which is highly specific for the gene of interest, (3) The fused trans-activating crRNA (tracrRNA) and crRNA sequence forms a stem-loop RNA structure that binds to the Cas9 enzyme; tracrRNA hybridizes and joins Cas9. (4) Assembly of sgRNA, attached with the target sequence and the Cas9 vector construct. (5) Transformation of the vector construct into rice via different transformation techniques. (5a) Screening and selection of rice mutant plants based on phenotypic changes. (5b) Restriction enzyme site loss generating a CRISPR/Cas9 mutagenized plant line. (c, control; m, mutagenized; RE, restrictions enzyme). (5c) Surveyor Assay (CEL1 and T7 are DNA endonucleases utilized in surveyor assay). (5d) Next-generation sequencing. (6) Future analysis to obtain T-DNA-free plants, and further experiments to prove phenotypic changes cast by the knockout of the gene under investigation. * Different techniques for the vector construct transformation. ${ }^{* *}$ Regeneration and screening of transgenic plants for gene editing events. 


\section{Genetics and Genomics of Rice Grain Quality}

Milling quality is based on the recovery of brown, milled, and head rice. It is a complex grain characteristic whose genetics are not fully understood. Over recent years, high throughput mapping technologies have enabled the identification of several major QTLs associated with rice quality. Two major QTLs ( $q B R R 3, q B R R 5)$, were mapped to chromosomes five and three, and these influence brown rice recovery $[27,28]$. The QTLs $q B R R 3$ and $q B R R 5$ were also found to regulate grain width and length [28]. Another study mapped the major QTL $q H R R 3$, located on chromosome three, and it is associated with head rice recovery and grain length $[27,29]$. Based on these studies, there is a strong link between grain size or shape and the percentage of head rice recovery. Consistently, four QTLs related to grain size, including GW2 [30], GW5 [31], GW8 [32], and GS5 [31], have also been cloned and functionally characterized. Concomitantly, their impact on cooking and eating qualities were also established. The Waxy $(W x)$ gene, on chromosome six, is an important gene which controls amylose content (AC), gel consistency (GC), and rapid visco analyzer pasting viscosity [33]. Additionally, many Wx alleles are present in different AC classes. Five prevalent classes of AC, glutinous, low, intermediate, high I, and high II contain five common alleles: $W x, W x^{t}, W x g^{1}, W x g^{2}$, and $W x g^{3}$, respectively [34]. Additionally, chalkiness is an integral component that determines the quality and ultimately the economic value of rice grain. Chalkiness negatively impacts appearance, milling, cooking, and nutritional qualities, as well as head rice recovery [35]. Chalkiness is largely determined by external and internal cues.

For example, rice cultivated at high temperatures has higher chalkiness, and genes involved in starch biosynthesis, grain filling, and starch granule structure all hamper chalkiness [36,37]. Based on these observations, genes controlling grain chalkiness, including $q P G W C-8$ [38] and $q P G W C-7$ [39], have been fine-mapped. However, the mechanism underlying the formation of grain chalkiness remains elusive.

Gelatinization temperature (GT) and amylopectin structure are controlled by a major QTL, SSIIa, which is located on chromosome six $[33,40,41]$. However, starch biosynthesis-related genes, such as SBE1, BE3, AGPlar, PUL, ISA, and starch synthesis genes, i.e., SSI, SSIIa, SSIII-2, and SSIV-2 all have effects on cooking and eating quality [42,43]. Starch biosynthesis pathways and genes/enzymes in rice endosperm are well characterized (Figure 2). A deletion within exon seven [44] or exon two [45] of the $B A D H 2$ gene, located on chromosome eight, increases the level of 2-acetyl-1-pyrroline (2AP) in fragrant rice. These mutations render $B A D H 2$ non-functional, resulting in increased 2AP [44]. However, the genetics and biochemical pathways of fragrance need further investigation [3]. In addition, a major QTL for protein content in rice, $q P C 1$, has been cloned and functionally characterized [46]. A major QTL responsible for crude fat content (FC) in brown rice, $q C F C 5$, is located on chromosome five [47]. QTLs controlling FC are governed by time-dependent gene expression; Wang et al. [48] revealed different expression patterns of FC-related QTLs at the grain filling stage. The possible mechanisms and QTLs responsible for amino acid content have been characterized by many researchers [49,50]. In addition, several QTLs responsible for mineral accumulation in rice have been characterized [51]. Based on these studies, QTLs controlling mineral accumulation in rice grain are largely environmentally regulated [52]. 


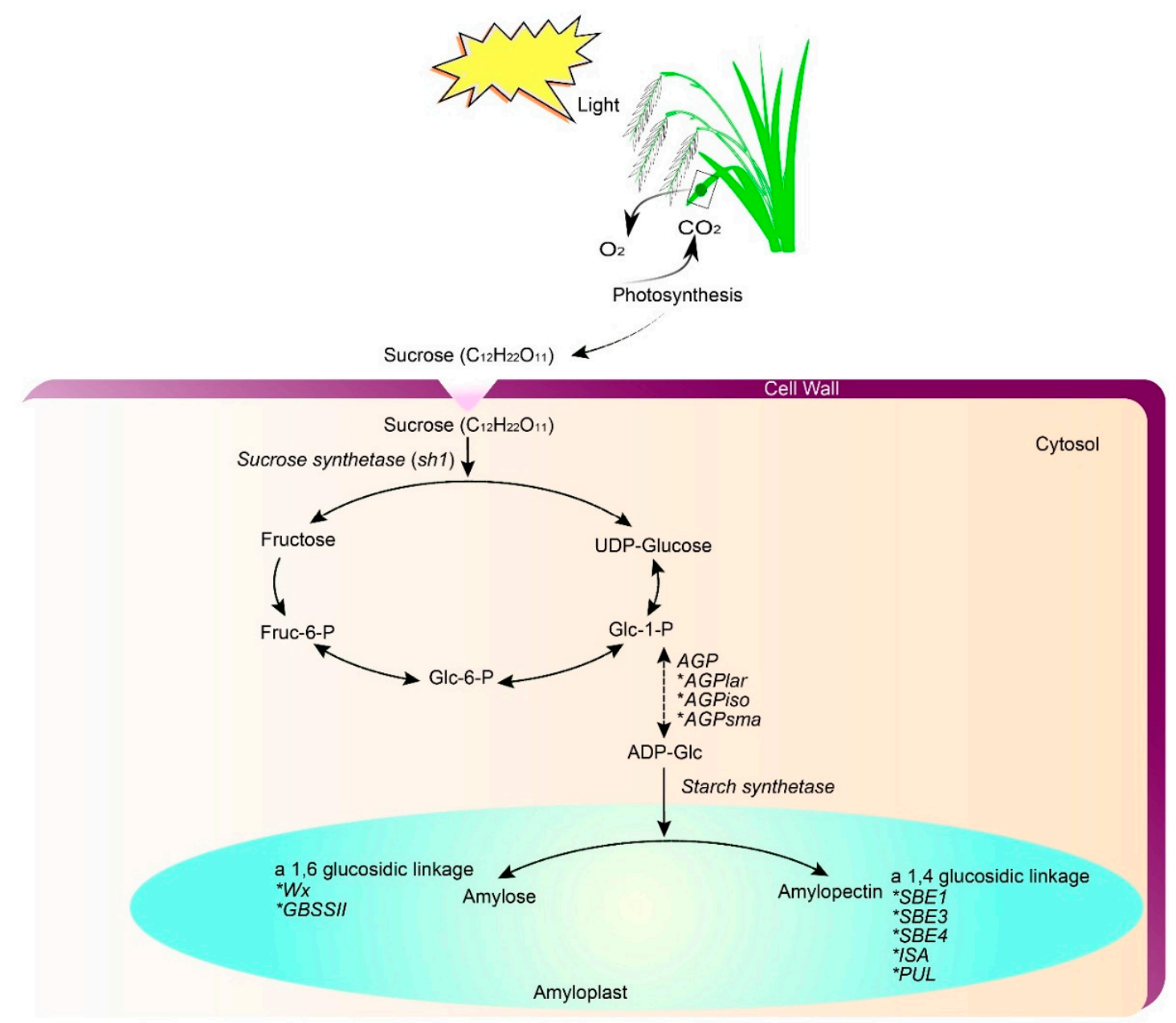

Figure 2. Starch biosynthesis pathway in cereals endosperm (modified from [18]). Eighteen genes play integral roles in different steps of starch synthesis. AGP, ADP-glucose pyrophosphorylase, AGPlar, AGP large subunit; AGPiso, AGP large subunit isoform; AGPsma, AGP small subunit; GBSS, granule bound starch synthase; SS, soluble starch synthase; SBE, starch branching enzyme; ISA, isoamylase; PUL, pullulanase; ISA and PUL belong to the starch debranching enzyme (DBE).

Traditionally studies on improving rice grain quality through genetic control have been conducted using biparental mapping populations, whilst the latest techniques of genome-wide association studies (GWASs) have allowed the understanding of the genetic basis of complex traits, i.e., grain quality. Although a sufficient number of studies [53-57] have been carried out using GWAS, and various genes/QTLs has been identified as well, which are associated with important grain quality parameters, further characterization of the identified candidates is needed. With the onset of next-generation sequencing, the construction of a high-resolution genetic map has become handy for to analyzing population genetics and for expression analysis. By employing this sequencing approach, Chen at al. [58] had constructed a high-density genetic map for a RIL population having 2711 recombination bin markers. They detected 12 QTL clusters, four of which matched the genomic regions of cloned genes or fine-mapped QTLs, i.e., GL7 [59], GS3 [60], gw5/qSW5 [61,62], and qPGWC-7 [63]. Besides that, eight other novel QTL clusters for grain shape and chalkiness were obtained [58]. The integration of the various -omics approaches, including genomics, transcriptomics, proteomics, metabolomics, etc., which can be termed as "multi-omics", may exploit underlying mechanisms to improve rice grain quality traits by understanding pathways for seed development and grain quality attributes [18], which definitely require extra capital and resources from other breeding platforms, i.e. bioinformatics. Based on the presented facts and the well-documented functional genomics of 
rice grain, along with the availability of genetic resources and the high transformation efficiency, the employment of the CRISPR/Cas9 system is a better choice for rice grain quality improvement.

\section{Applications of CRISPR/Cas9 for Rice Grain Quality Improvement}

The improvement of rice grain quality attributes via targeted genome editing is a fast, sustainable, and cost-effective approach. The application of CRISPR/Cas9 requires multiple processes. The initial step is to discover genes of significant importance. The genes that negatively regulate the grain quality, can be referred to as Q-genes (any plant gene that facilitates the degradation process of rice grain quality when expressed). Both forward and reverse genetics approaches can identify the genes that are responsible for phenotypic variation [3]. Conventional plant breeding tools mainly depend on naturally existing germplasm variations. The introgression of desirable traits into the selected germplasm requires successive backcrossing, followed by the screening of large populations, which requires much time and energy. However, reverse genetic approaches enhance the speed of plant breeding through targeted genome modification (Figure 3). The available literature on CRISPR/Cas9 has promoted its application towards the genetic improvement of O. sativa L. (Table 1, Figure 4).

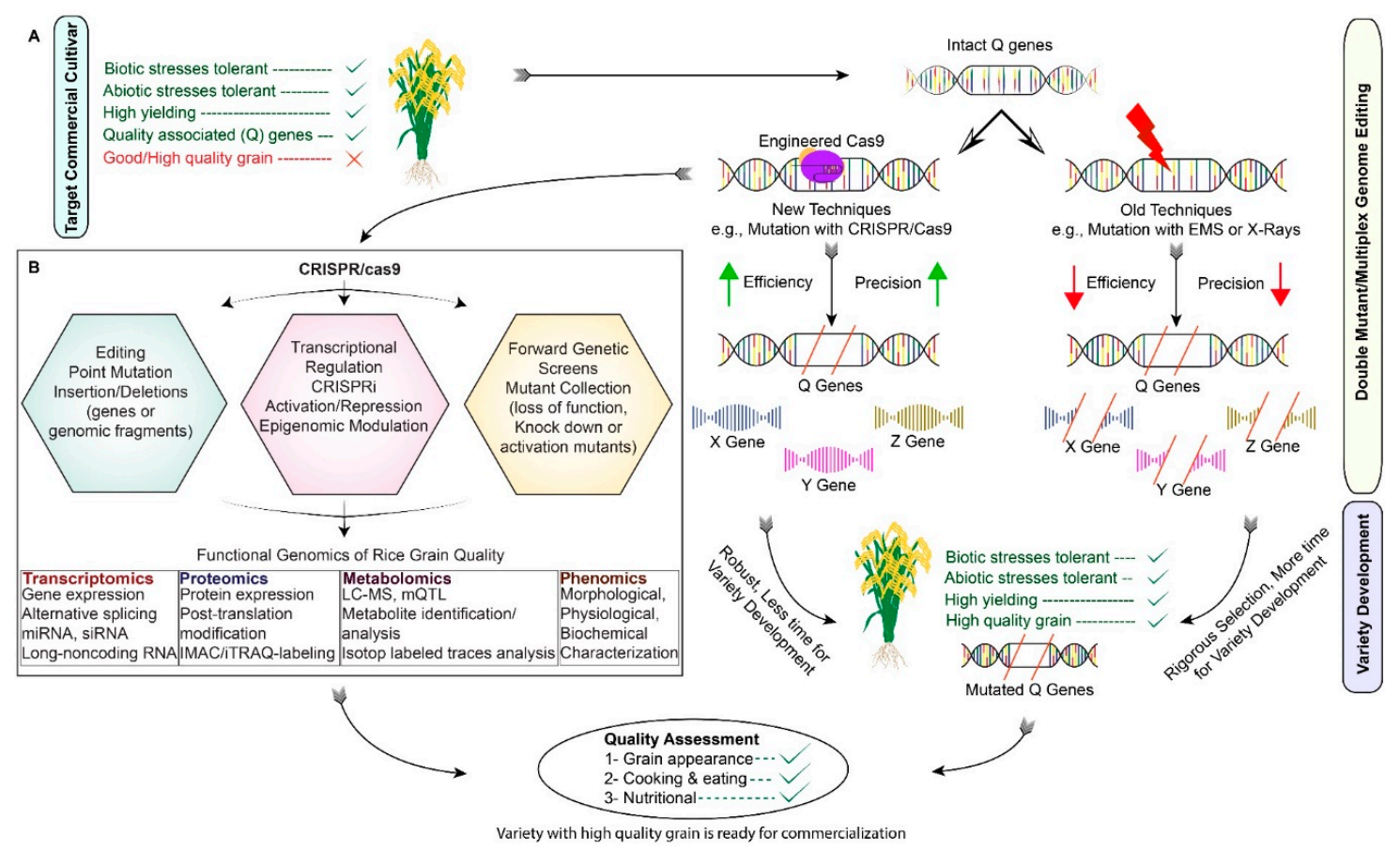

Figure 3. An illustration of rice grain quality improvement through the CRISPR/Cas9 system. (A) Advantages of CRISPR-mediated gene editing over conventional breeding techniques to develop rice varieties with high grain quality. (B) An overview of the applications of CRISPR-Cas9 system in the functional genomics of rice grain quality improvement. The CRISPR-Cas9 system can be used for genome editing (via the introduction of point mutations, insertions or deletions), transcriptional regulation (via CRISPRi (CRISPR interference), activation, repression, or epigenetic modulation) or forward genetics screens (via the generation of loss-of-function, knock-down, or activation mutants using sgRNA libraries) for understanding the molecular basis of rice grain quality, which can lead to the generation of crop plants with excellent quality grain. 


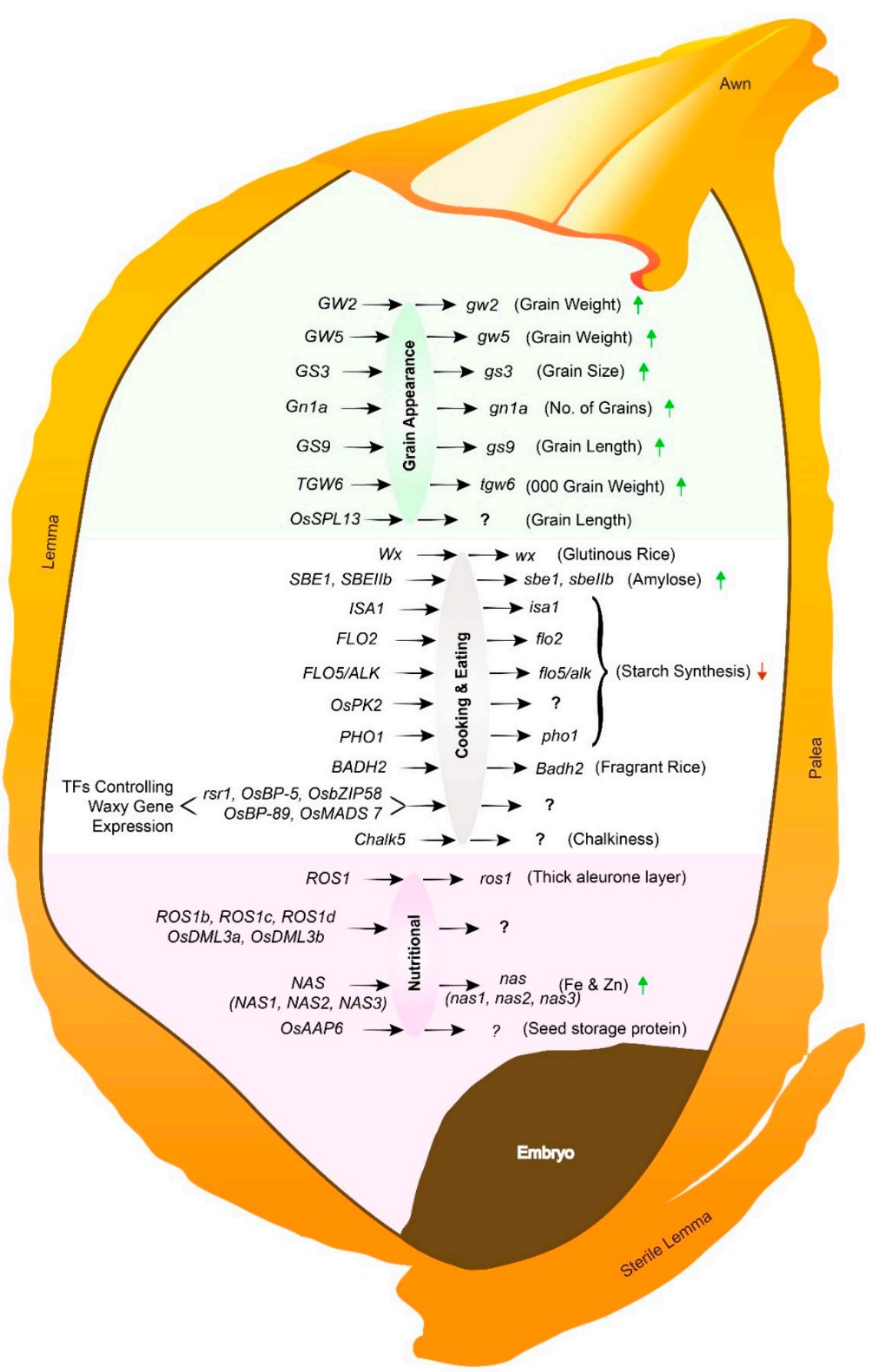

Figure 4. Genes responsible for rice grain quality, parallel to their mutated function. ? = potential genes for editing via CRISPR/Cas9 to improve the grain quality of rice varieties; red downward arrows $(\downarrow)$ represent a decrease in traits, whereas green upward arrows ( $\uparrow$ ) represent an increase/improvement in traits when their respective genes are mutated. 
Table 1. CRISPR-Cas9-edited genes in O. sativa L.

\begin{tabular}{|c|c|c|c|c|c|c|}
\hline $\begin{array}{l}\text { Application } \\
\text { Prospective }\end{array}$ & Target Gene & Cas9 Version & Cas9 Promoter & sgRNA Promoter & $\begin{array}{l}\text { Transformation } \\
\text { Method }\end{array}$ & Reference \\
\hline \multirow{6}{*}{ Quality Improvement } & Waxy & $\mathrm{N} / \mathrm{A}$ & $35 \mathrm{~S}$ & OsU6 & \multirow{6}{*}{$\begin{array}{l}\text { Agrobacterium-mediated } \\
\text { transformation }\end{array}$} & [64] \\
\hline & SBE1, SBEIIb & Codon-optimized Cas9 & ZmUbi & OsU3 & & [65] \\
\hline & ISA1 & Rice codon-optimized & $35 \mathrm{~S}$ & OsU6 & & [66] \\
\hline & OsPDS, OsBADH2, Oso2g23823, OsMPK2 & Rice codon-optimized & $2 \times 35 S$ & OsU3 & & [67] \\
\hline & OsCYP97A4, OsDSM2, OsCCD4a, OsCCD4b, and OsCCD7 & Rice codon-optimized & $35 \mathrm{~S}$ & OsU3 & & [68] \\
\hline & OsNramp5 & Rice codon-optimized & CaMV35S & OsU6a & & [69] \\
\hline \multirow{5}{*}{ Yield Improvement } & Gn1a, DEP1, GS3, IPA1 & Codon-optimized Cas9 & OsUbi & OsU6a & \multirow{5}{*}{$\begin{array}{l}\text { Agrobacterium-mediated } \\
\text { transformation }\end{array}$} & [70] \\
\hline & GLW2 & Plant codon-optimized & $2 \times 35 S$ & OsU6 & & [70] \\
\hline & GS9 & Rice codon-optimized & CaMV $35 \mathrm{~S}$ & OsU3 & & [71] \\
\hline & GW2, GW5 and TGW6 & Codon-optimized Cas9 & OsUbi & OsU3, OsU6 and TaU3 & & [72] \\
\hline & TMS5 & Codon-optimized Cas 9 & OsU3/U6 & OsU3/U6 & & [73] \\
\hline \multirow{4}{*}{ Disease resistance } & OsERF922 & Codon-optimized Cas9 & CaMV 35S & OsU6 & \multirow{4}{*}{$\begin{array}{l}\text { Agrobacterium-mediated } \\
\text { transformation }\end{array}$} & [74] \\
\hline & Bsrk1 & Rice codon-optimized & $35 \mathrm{~S}$ & OsU6 & & [75] \\
\hline & ALS & Rice codon-optimized & $2 \times \mathrm{P} 35 \mathrm{~S}$ & OsU6 & & [76] \\
\hline & OsAnn3 & Codon-optimized Cas9 & CaMV35S & OsU6 & & [77] \\
\hline
\end{tabular}




\subsection{Improving Rice Grain Appearance and Milling Quality}

Many genes responsible for rice grain appearance quality have been identified, and have the potential to be tapped with CRISPR/Cas9 technology. Grain appearance is the primary quality attribute that influences the market acceptability of rice [17]. However, another important quality trait is the grain chalkiness, which is an undesirable quality attribute, which results in low market acceptability [78]. Grain shape is regarded as a yield component, and it plays a key role in determining the quality of rice grains. Recently, GS3, responsible for grain length, and Gn1a, controlling the number of grains, have been successfully edited in four rice varieties [79]. The transgene-free $\mathrm{T}_{1}$ plants showed longer grain lengths and increased thousand grain weights in comparison to the wild type. Similarly, three other important genes GW2, GW5, and TGW6, negative regulators of grain weight, were targeted through CRISPR/Cas9-mediated multiplex genome editing. The obtained results indicated that the genome editing of these genes significantly increased grain size and thousand grain weight [72]. There are several identified genes for these traits, and their interactions and functions have been fully characterized. The integration of functionally characterized genes/QTLs, i.e., OsSPL13, OsSPL16/GW8, GW7, and Chalk5, through knock-in/out using CRISPR/Cas9, and the assessment of their interactions among genes, can greatly improve our understanding of rice grain appearance and milling quality.

\subsection{Improving Rice Grain Cooking and Eating Quality}

Generally, three important physicochemical indices comprising amylose content (AC), gel consistency, and the gelatinization temperature (GT), altogether determine the cooking and eating quality of rice grain. All three indices define $(\sim 90 \%)$ the starch properties of hulled rice. Rice with good cooking and eating quality determines the cooking ease, along with the firmness and the stickiness features [80]. AC is regulated by the Wx gene in the endosperm [81], and ALK/SSIIa and RSR1 control GT [82]. Several studies have been conducted to unearth the roles of different genes and/or enzymes involved in the regulation and expression of the $W x$ gene. Wu et al. [83] reported that dozens of dull genes affect the splicing efficiency of $W x$, and they characterized a tetratricopeptide domain-containing flo2 protein regulating the expression of $W x$. Similarly, transcription factors like rsr1, OsBP-5, OsEBP-89, OsbZIP58, and OsMADS7 modified $W x$ expression $[84,85]$. The indica hybrids, especially in China, are high in AC, and become hard and dry during cooking. Ma et al. [86] successfully edited the $W x$ gene in the japonica background, leading to reduced AC. Moreover, transgenic Taichung 65 rice lines containing a $W x$ antisense construct had lower $A C$, and hybrids obtained from these transgenic lines also showed reduced AC [87]. In comparison, [64,84] introduced a loss-of-function mutation via CRISPR/Cas9 to the Wx gene in two widely grown japonica cultivars, "Xiushui134" and "Wuyunjing 7". The Wx gene mutation led to reduced AC, and offered an effective strategy to improve elite cultivars without any penalty in other desirable agronomic traits. To understand the fine structure and physical properties of starch SBEI and SBEII, they were mutated via targeted mutagenesis. The results demonstrated that $S B E I I b$ plays an important role in creating high-amylose rice. The fragrant gene Badh2 in Zhonghua 11 was edited by the CRISPR/Cas9 mutagenesis system. The mutated line contained an additional $\mathrm{T}$ base in the first exon of Badh2, and resulted in an increased amount of 2AP, and enhanced fragrance in rice [88]. The successful editing of these genes has proven that this system could be the best method for understanding the functional aspects of genes and transcriptional factors influencing cooking and eating quality.

\subsection{Improving Rice Grain of Nutritional Quality}

Food nutritional quality improvement has great importance worldwide, especially in developing countries where many people rely on rice as their staple food. Additionally, approximately 24,000 people die daily globally, owing to malnutrition [89,90]. People are eating foods that are deficient in protein, energy, iron, zinc, vitamin A, and iodine [91]. However, improving rice grain nutritional quality using CRISPR/Cas9 system can overcome this issue. The content of seed storage proteins 
(SSPs), fats, amino acids, vitamins, and other micronutrients determines the nutritional quality of rice grain [46], but rice has the lowest protein content of the cereal grains [92]. However, the protein is the second most abundant ingredient of hulled rice after starch contents, in that the lysine is amongst the limiting essential amino acids, as per human nutrition standards [17]. Certain amino acids such as lysine (Lys) and tryptophan (Trp) are missing from the SSPs of rice grain [93,94]. Therefore, improving nutrition in humans is intriguingly associated with improving nutrition in SSPs, especially for people in regions where rice is a staple food. Rice contains six 5-methylcytosine $(5 \mathrm{mC})$ DNA methylase genes, including OsROS1, OsROS1b, OsROS1c, OsROS1d, OsDML3a, and OsDML3b, which can play an important role in enhancing nutritional grain quality. The number of aleurone cell layers was increased by ta2-1, which is a weak mutant allele of OsROS1 [95]. Approaches to improve protein and essential amino acids in rice seeds by transgenic engineering have been attempted by many research groups, e.g., the expression of AmA1 seed albumin [96], the overexpression of aspartate aminotransferase genes [39], the transfer of two artificially synthesized genes [97], the production of engineered rice [68], the transfer of wheat glutelin gene Glu-1D $\times 5$ [98], and the expression of a gene encoding a precursor polypeptide of sesame $2 \mathrm{~S}$ albumin [99].

The SSPs include four different categories in rice, albumin, globulin, prolamin, and glutelin, separated by their solubility [100]. In rice, SSP genes have been cloned and characterized mostly by mutant screening [101]. Movement of the ferritin gene from common bean into rice has been made possible by transgenic approaches [102]. The concentration of Fe in ferritin-containing rice lines was double the concentration in controls. In addition, Vasconcelos et al. [103] transferred the ferritin gene from soybean into rice, and recorded Fe concentrations. Interestingly, it was increased by three- and two-fold in milled and rough rice, respectively. Similarly, Khalekuzzaman et al. [104] introduced the ferritin gene driven by an endosperm-specific glutelin promoter, and found increased Fe concentration in brown and polished seeds of $T_{1}$ and $T_{2}$ populations of the cultivar, BRRl Dhan 29 (BR29), respectively, in comparison with controls. Thus, the Fe content was increased by over two-fold in transgenic lines. Subsequently, many researchers have attempted to increase Fe content in rice endosperm using different methods such as: (1) overexpressing the genes involved in Fe uptake from the soil; (2) moving Fe into the grain from the root, shoot and flag leaf; and (3) increasing the efficiency of Fe storage proteins [105-107]. The nicotianamine synthase (NAS) gene from Hordeum vulgare L. has been successfully transferred into rice, which significantly improved the contents of Fe and Zn by two- or three-fold in polished rice grain. In another study, Zheng et al. [108] observed that the overexpression of endosperm-specific endogenous NAS genes (OsNAS1, OsNAS2, and OsNAS3) increased Fe accumulation by five-fold in polished rice grain. In addition, Johnson et al. [109] recorded a two-fold increase of $\mathrm{Fe}$ and $\mathrm{Zn}$ concentration in polished rice overexpressing single rice OsNAS genes. $\beta$-carotene, which is the precursor of vitamin $\mathrm{A}$, cannot be produced by rice. Therefore, researchers developed golden rice, which rich in $\beta$-carotene, by the introgression of two genes, including phytoene synthase and phytoene desaturase, to overcome night blindness caused by vitamin A deficiency in many developing countries [110]. Briefly, all of these genes have been manipulated/introgressed from different biological backgrounds approaches.

However, these approaches have some limitations, such as being time consuming, involving the introduction of foreign DNA, off-target genome modifications, the association of undesirable traits with target attributes, and the lower efficiency makes them a hard choice for researchers. However, improving rice grain nutritional quality using the CRISPR/Cas9 system can overcome these issues. The CRISPR/Cas9 system was used to knock out five rice carotenoid catabolic genes (OsCYP97A4, OsDSM2, OsCCD4a, OsCCD4b, and OsCCD7), and to increase $\beta$-carotene accumulation in rice endosperm [111]. However, it was found that the targeted mutations in five carotenoid catabolism genes failed to boost carotenoid accumulation in rice seeds, which needs further investigations to make the following approach reliable. Multiplex editing is an easy and well-understood system, especially for comparing and dissecting the functions and relationships of major genes/QTLs [72]. In the rice genome, up to 46 target sites were edited, with an average of $85.4 \%$ mutation frequency [86]. The study also confirmed the 
immediate editing of three sites within the gene OsWaxy, which caused an amylose content reduction (up to 14\%). Multiplex genome editing was also testified with the help of endogenous transfer RNA (tRNA) processing system in rice, wherever each sgRNA was flanked by tRNA and processed into single sgRNAs, which caused large deletions in the genomic sequences of the $\mathrm{T}_{0}$ generation [112]. Likewise, it a new strategy was reported in rice for the CRISPR/Cas9-sgRNA multiplex editing system, where $21 \mathrm{sgRNAs}$ were designed, and the equivalent Cas9/sgRNAs expression vectors were created [113]. Transformed rice plants were successfully and significantly edited, and up to $82 \%$ of the desired target sites represented deletion, insertion, substitution, and inversion events, thus exhibiting high editing efficiency. All of these reports clearly show that CRISPR/Cas9 is the best method for rapidly validating the function of genes, and thereby testing many genes simultaneously. It can be used to establish proofs of concept before targeting the genes that are directly involved in the quality of the rice grain.

\section{Beyond Rice Grain Quality Improvement}

Over the last few years, GETs have revolutionized crop improvement programs. Newly developed crop varieties have improved traits including high yield, resistance against different diseases, and biotic and abiotic stresses. Firstly, the knockout of genes that have a great influence on grain yield, such as GS3, DEP1, GS5, GW2, Gnla, and TGW6, is a simple and direct method for improving average rice yields. The mutants of these genes give the desired, impressive phenotypes [70,114]. The development of a rice triple mutant by simultaneously knocking out GW2, GW5, and TGW6 increased the thousand grain weight significantly [72]. Moreover, hybrid rice production can also be increased by using TMS5 mutant lines $[115,116]$. Multiple disease resistance lines have also been obtained via CRISPR/Cas 9 technology. The knockout of the rice blast resistance gene OsERF922 showed significant reduction in blast lesion formation under pathogen infection [74]. A knockout of the blast resistance gene Bsrk-1 enhanced the resistance of rice without compromising yield [75]. Moreover, herbicide resistance research was initiated to ensure public and environmental health, as both are influenced by agrochemical use [117]. ALS1 is one of the main enzymes responsible for the herbicide resistance of rice. Sun, Zhang, $\mathrm{Wu}, \mathrm{He}$, $\mathrm{Ma}, \mathrm{Hou}, \mathrm{Guo}, \mathrm{Du}$, Zhao and Xia [76] carried out mutations at multiple discrete points in the rice $A L S$ gene using CRISPR/Cas9. The results showed that CRISPR/Cas9-mediated homology-directed repair was successful. Xu et al. [118] targeted the second exon of BEL in the Nipponbare rice cultivar, related to bentazon and sulfonylurea herbicide resistance, through CRISPR/Cas9. The phenotypic screening matched the results of the genetic mutant screening. Additionally, the seedling stage of rice is more vulnerable to low temperatures. TIFY1b, a transcription factor, and the OsAnn3 gene in rice were edited through CRISPR/Cas9, which enhanced cold tolerance significantly. In addition, knockout of the OsNramp5 transporter gene for cadmium (Cd) led to the development of rice hybrid lines with low $\mathrm{Cd}$ accumulation. The mutant osnramp5 showed less accumulation of $\mathrm{Cd}$ in roots, shoots, and seeds $[69,119]$. Hence, genome editing using the CRISPR/Cas9 system has contributed a lot to the manipulation of plant genomes, but there is still great potential to be tapped.

\section{Conclusions and Future Perspectives}

Premium quality rice grain is the demand of a growing population with better living standards. Presently, the CRISPR/Cas9 system has all genome editing capabilities, e.g., knock-in, knockout, knockdown, and expression activation. This system has tremendous untapped potential, has formed an ever-expanding genetic toolbox for plant biologists to investigate functional genomics, and is a helping hand for breeders to integrate important genes into the genomes of important crops. The successful application of CRISPR/Cas9 for tissue engineering and human stem cell modification has led to further developments in the field of precise genome editing. The ability to target multiple genes via multiplexed genome editing strategies can facilitate pathway-level research to engineer complex multigenic rice grain quality attributes. Previously, few studies have been conducted that are related to targeted mutagenesis for rice grain quality improvement. The pathways of rice grain quality are 
not well understood, and they can be investigated for the genetic mechanisms controlling quality attributes. The development of novel regulatory components from naturally existing peripherals (genes, promoters, cis-regulatory elements, small RNAs, and epigenetic modifications) can facilitate the engineering of regulatory pathways for different elements of rice grain quality. The rapid shift of research toward the utilization of CRISPR/Cas9 systems for targeted mutagenesis could be a promising approach for overcome barriers to breeding improved quality rice.

Author Contributions: S.F. and S.A. conceived the idea. M.A.N., X.W., A.Y. and A.R. (Adeel Riaz) provided the literature and technical assistance. S.F. and S.A., drafted manuscript and illustrations. M.A.N., F.A., and A.R. (Aamir Riaz) helped in editing the manuscript. All authors listed have made substantial, direct, and intellectual contributions to the work, and approved it for publication.

Funding: The publication of present work was supported by the National Key Research and Development Program of China (grant no. 2017YFC0504704), and the National Natural Science Foundation of China (51669034, $41761068,51809224)$.

Acknowledgments: The authors are thankful to Xiangjin Wei for providing insightful suggestions on the figures.

Conflicts of Interest: The authors have no competing interest to be declared.

\section{References}

1. Parmar, R.R.; Jain, K.R.; Modi, C.K. Unified approach in food quality evaluation using machine vision. In Proceedings of the International Conference on Advances in Computing and Communications, Kochi, India, 22-24 July 2011; pp. 239-248.

2. Sabouri, A.; Rabiei, B.; Toorchi, M.; Aharizad, S.; Moumeni, A. Mapping quantitative trait loci (QTL) associated with cooking quality in rice ('Oryza sativa' L.). Aust. J. Crop Sci. 2012, 6, 808.

3. Lau, W.C.; Rafii, M.Y.; Ismail, M.R.; Puteh, A.; Latif, M.A.; Ramli, A. Review of functional markers for improving cooking, eating, and the nutritional qualities of rice. Front. Plant Sci. 2015, 6, 832. [CrossRef] [PubMed]

4. Cruz, N.D.; Khush, G. Rice grain quality evaluation procedures. Aromat. Rices 2000, 3, 15-28.

5. Rebeira, S.; Wickramasinghe, H.; Samarasinghe, W.; Prashantha, B. Diversity of grain quality characteristics of traditional rice (Oryza sativa L.) varieties in Sri Lanka. Trop. Agric. Res. 2014, 25, 470-478. [CrossRef]

6. Jain, M. Function genomics of abiotic stress tolerance in plants: A CRISPR approach. Front. Plant Sci. 2015, 6, 375. [CrossRef] [PubMed]

7. Zhang, W.; Sun, P.; He, Q.; Shu, F.; Wang, J.; Deng, H. Fine mapping of GS2, a dominant gene for big grain rice. Crop J. 2013, 1, 160-165. [CrossRef]

8. Xie, W.; Wang, G.; Yuan, M.; Yao, W.; Lyu, K.; Zhao, H.; Yang, M.; Li, P.; Zhang, X.; Yuan, J. Breeding signatures of rice improvement revealed by a genomic variation map from a large germplasm collection. Proc. Natl. Acad. Sci. USA 2015, 112, E5411-E5419. [CrossRef] [PubMed]

9. Svitashev, S.; Schwartz, C.; Lenderts, B.; Young, J.K.; Cigan, A.M. Genome editing in maize directed by CRISPR-Cas9 ribonucleoprotein complexes. Nat. Commun. 2016, 7, 13274. [CrossRef] [PubMed]

10. Zischewski, J.; Fischer, R.; Bortesi, L. Detection of on-target and off-target mutations generated by CRISPR/Cas9 and other sequence-specific nucleases. Biotechnol. Adv. 2017, 35, 95-104. [CrossRef]

11. Karvelis, T.; Gasiunas, G.; Young, J.; Bigelyte, G.; Silanskas, A.; Cigan, M.; Siksnys, V. Rapid characterization of CRISPR-Cas9 protospacer adjacent motif sequence elements. Genome Biol. 2015, 16, 253. [CrossRef]

12. Ran, F.A.; Cong, L.; Yan, W.X.; Scott, D.A.; Gootenberg, J.S.; Kriz, A.J.; Zetsche, B.; Shalem, O.; Wu, X.; Makarova, K.S. In vivo genome editing using Staphylococcus aureus Cas9. Nature 2015, 520, 186. [CrossRef]

13. Geng, Y.; Deng, Z.; Sun, Y. An insight into the protospacer adjacent motif of Streptococcus pyogenes Cas 9 with artificially stimulated RNA-guided-Cas9 DNA cleavage flexibility. RSC Adv. 2016, 6, 33514-33522. [CrossRef]

14. Steinert, J.; Schiml, S.; Fauser, F.; Puchta, H. Highly efficient heritable plant genome engineering using Cas9 orthologues from Streptococcus thermophilus and Staphylococcus aureus. Plant J. 2015, 84, 1295-1305. [CrossRef] [PubMed]

15. Jacobs, T.B.; LaFayette, P.R.; Schmitz, R.J.; Parrott, W.A. Targeted genome modifications in soybean with CRISPR/Cas9. BMC Biotechnol. 2015, 15, 16. [CrossRef] [PubMed] 
16. Chang, Z.; Yan, W.; Liu, D.; Chen, Z.; Xie, G.; Lu, J.; Wu, J.; Tang, X. Research progress on CRISPR/Cas. J. Agric. Biotechnol. 2015, 23, 1196-1206.

17. Bao, J. Genes and QTLs for rice grain quality improvement. In Rice-Germplasm, Genetics and Improvement; InTech: London, UK, 2014.

18. Bao, J. Biotechnology for rice grain quality improvement. In Rice; AACC International Press: St. Paul, MN, USA, 2019; pp. 443-471.

19. Bandyopadhyay, A.; Yin, X.; Biswal, A.; Coe, R.; Quick, W.P. CRISPR-Cas9-Mediated Genome Editing of Rice Towards Better Grain Quality. In Rice Grain Quality; Springer: Berlin/Heidelberg, Germany, 2019; pp. 311-336.

20. Mishra, R.; Joshi, R.K.; Zhao, K. Genome editing in rice: Recent advances, challenges, and future implications. Front. Plant Sci. 2018, 9, 1361. [CrossRef] [PubMed]

21. Heigwer, F.; Kerr, G.; Boutros, M. E-CRISP: Fast CRISPR target site identification. Nat. Methods 2014, 11, 122. [CrossRef] [PubMed]

22. Prykhozhij, S.V.; Rajan, V.; Gaston, D.; Berman, J.N. CRISPR multitargeter: A web tool to find common and unique CRISPR single guide RNA targets in a set of similar sequences. PLoS ONE 2015, 10, e0119372.

23. Doench, J.G.; Fusi, N.; Sullender, M.; Hegde, M.; Vaimberg, E.W.; Donovan, K.F.; Smith, I.; Tothova, Z.; Wilen, C.; Orchard, R. Optimized sgRNA design to maximize activity and minimize off-target effects of CRISPR-Cas9. Nat. Biotechnol. 2016, 34, 184. [CrossRef]

24. Pliatsika, V.; Rigoutsos, I. "Off-Spotter": Very fast and exhaustive enumeration of genomic lookalikes for designing CRISPR/Cas guide RNAs. Biol. Direct 2015, 10, 4. [CrossRef]

25. Stemmer, M.; Thumberger, T.; del Sol Keyer, M.; Wittbrodt, J.; Mateo, J.L. CCTop: An intuitive, flexible and reliable CRISPR/Cas9 target prediction tool. PLoS ONE 2015, 10, e0124633. [CrossRef] [PubMed]

26. Bortesi, L.; Fischer, R. The CRISPR/Cas9 system for plant genome editing and beyond. Biotechnol. Adv. 2015, 33, 41-52. [CrossRef] [PubMed]

27. Tan, Y.; Sun, M.; Xing, Y.; Hua, J.; Sun, X.; Zhang, Q.; Corke, H. Mapping quantitative trait loci for milling quality, protein content and color characteristics of rice using a recombinant inbred line population derived from an elite rice hybrid. Theor. Appl. Genet. 2001, 103, 1037-1045. [CrossRef]

28. Lou, J.; Chen, L.; Yue, G.; Lou, Q.; Mei, H.; Xiong, L.; Luo, L. QTL mapping of grain quality traits in rice. J. Cereal Sci. 2009, 50, 145-151. [CrossRef]

29. Jiang, W.; Bikard, D.; Cox, D.; Zhang, F.; Marraffini, L.A. RNA-guided editing of bacterial genomes using CRISPR-Cas systems. Nat. Biotechnol. 2013, 31, 233. [CrossRef] [PubMed]

30. Song, X.-J.; Huang, W.; Shi, M.; Zhu, M.-Z.; Lin, H.-X. A QTL for rice grain width and weight encodes a previously unknown RING-type E3 ubiquitin ligase. Nat. Genet. 2007, 39, 623. [CrossRef] [PubMed]

31. Wan, X.; Weng, J.; Zhai, H.; Wang, J.; Lei, C.; Liu, X.; Guo, T.; Jiang, L.; Su, N.; Wan, J. QTL analysis for rice grain width and fine mapping of an identified QTL allele $g w-5$ in a recombination hotspot region on chromosome 5. Genetics 2008, 179, 2239-2252. [CrossRef]

32. Wang, S.; Wu, K.; Yuan, Q.; Liu, X.; Liu, Z.; Lin, X.; Zeng, R.; Zhu, H.; Dong, G.; Qian, Q. Control of grain size, shape and quality by OsSPL16 in rice. Nat. Genet. 2012, 44, 950. [CrossRef]

33. Lapitan, V.C.; Redoña, E.D.; Abe, T.; Brar, D.S. Mapping of quantitative trait loci using a doubled-haploid population from the cross of Indica and Japonica cultivars of rice. Crop Sci. 2009, 49, 1620-1628. [CrossRef]

34. Teng, B.; Zeng, R.; Wang, Y.; Liu, Z.; Zhang, Z.; Zhu, H.; Ding, X.; Li, W.; Zhang, G. Detection of allelic variation at the $\mathrm{Wx}$ locus with single-segment substitution lines in rice (Oryza sativa L.). Mol. Breed. 2012, 30, 583-595. [CrossRef]

35. Nevame, A.; Emon, R.; Malek, M.; Hasan, M.; Alam, M.; Muharam, F.M.; Aslani, F.; Rafii, M.; Ismail, M. Relationship between High Temperature and Formation of Chalkiness and Their Effects on Quality of Rice. BioMed Res. Int. 2018, 2018, 1653721. [CrossRef] [PubMed]

36. Yamakawa, H.; Hirai-Kimura, R.; Nakata, Y.; Nakata, M.; Kuroda, M.; Yamaguchi, T. An activity-staining method on filtration paper enables high-throughput screening of temperature-sensitive and inactive mutations of rice $\alpha$-amylase for improvement of rice grain quality. Plant Cell Physiol. 2017, 58, 658-667. [CrossRef] [PubMed]

37. Bergman, C.J. Rice end-use quality analysis. In Rice; AACC International Press: St. Paul, MN, USA, 2019; pp. 273-337. 
38. Guo, T.; Liu, X.; Wan, X.; Weng, J.; Liu, S.; Liu, X.; Chen, M.; Li, J.; Su, N.; Wu, F. Identification of a stable quantitative trait locus for percentage grains with white chalkiness in rice (Oryza sativa). J. Integr. Plant Biol. 2011, 53, 598-607. [CrossRef] [PubMed]

39. Zhou, Y.; Cai, H.; Xiao, J.; Li, X.; Zhang, Q.; Lian, X. Over-expression of aspartate aminotransferase genes in rice resulted in altered nitrogen metabolism and increased amino acid content in seeds. Theor. Appl. Genet. 2009, 118, 1381-1390. [CrossRef] [PubMed]

40. Umemoto, T.; Yano, M.; Satoh, H.; Shomura, A.; Nakamura, Y. Mapping of a gene responsible for the difference in amylopectin structure between japonica-type and indica-type rice varieties. Theor. Appl. Genet. 2002, 104, 1-8. [CrossRef] [PubMed]

41. Wang, L.; Liu, W.; Xu, Y.; He, Y.; Luo, L.; Xing, Y.; Xu, C.; Zhang, Q. Genetic basis of 17 traits and viscosity parameters characterizing the eating and cooking quality of rice grain. Theor. Appl. Genet. 2007, 115, 463-476. [CrossRef] [PubMed]

42. Bao, J.; Wu, Y.; Hu, B.; Wu, P.; Cui, H.; Shu, Q. QTL for rice grain quality based on a DH population derived from parents with similar apparent amylose content. Euphytica 2002, 128, 317-324. [CrossRef]

43. Tian, Z.; Qian, Q.; Liu, Q.; Yan, M.; Liu, X.; Yan, C.; Liu, G.; Gao, Z.; Tang, S.; Zeng, D. Allelic diversities in rice starch biosynthesis lead to a diverse array of rice eating and cooking qualities. Proc. Natl. Acad. Sci. USA 2009, 106, 21760-21765. [CrossRef]

44. Bradbury, L.M.; Fitzgerald, T.L.; Henry, R.J.; Jin, Q.; Waters, D.L. The gene for fragrance in rice. Plant Biotechnol. J. 2005, 3, 363-370. [CrossRef]

45. Shi, W.; Yang, Y.; Chen, S.; Xu, M. Discovery of a new fragrance allele and the development of functional markers for the breeding of fragrant rice varieties. Mol. Breed. 2008, 22, 185-192. [CrossRef]

46. Peng, B.; Kong, H.; Li, Y.; Wang, L.; Zhong, M.; Sun, L.; Gao, G.; Zhang, Q.; Luo, L.; Wang, G. OsAAP6 functions as an important regulator of grain protein content and nutritional quality in rice. Nat. Commun. 2014, 5, 4847. [CrossRef] [PubMed]

47. Qin, Y.; Kim, S.-M.; Zhao, X.; Lee, H.-S.; Jia, B.; Kim, K.-M.; Eun, M.-Y.; Sohn, J.-K. QTL detection and MAS selection efficiency for lipid content in brown rice (Oryza sativa L.). Genes Genom. 2010, 32, 506-512. [CrossRef]

48. Wang, H.; Zhang, W.; Liu, L.; Shen, Y.; Wang, J.; Jiang, L.; Zhai, H.; Wan, J. Dynamic QTL analysis on rice fat content and fat index using recombinant inbred lines. Cereal Chem. 2008, 85, 769-775. [CrossRef]

49. Bruno, E.; Choi, Y.-S.; Chung, I.K.; Kim, K.M. QTLs and analysis of the candidate gene for amylose, protein, and moisture content in rice (Oryza sativa L.). 3 Biotech 2017, 7, 40. [CrossRef] [PubMed]

50. Mahender, A.; Anandan, A.; Pradhan, S.K.; Pandit, E. Rice grain nutritional traits and their enhancement using relevant genes and QTLs through advanced approaches. Springer Plus 2016, 5, 2086. [CrossRef] [PubMed]

51. Norton, G.J.; Deacon, C.M.; Xiong, L.; Huang, S.; Meharg, A.A.; Price, A.H. Genetic mapping of the rice ionome in leaves and grain: Identification of QTLs for 17 elements including arsenic, cadmium, iron and selenium. Plant Soil 2010, 329, 139-153. [CrossRef]

52. Du, J.; Zeng, D.; Wang, B.; Qian, Q.; Zheng, S.; Ling, H.-Q. Environmental effects on mineral accumulation in rice grains and identification of ecological specific QTLs. Environ. Geochem. Health 2013, 35, 161-170. [CrossRef]

53. Huang, X.; Sang, T.; Zhao, Q.; Feng, Q.; Zhao, Y.; Li, C.; Zhu, C.; Lu, T.; Zhang, Z.; Li, M. Genome-wide association studies of 14 agronomic traits in rice landraces. Nat. Genet. 2010, 42, 961. [CrossRef]

54. Zhao, K.; Tung, C.-W.; Eizenga, G.C.; Wright, M.H.; Ali, M.L.; Price, A.H.; Norton, G.J.; Islam, M.R.; Reynolds, A.; Mezey, J. Genome-wide association mapping reveals a rich genetic architecture of complex traits in Oryza sativa. Nat. Commun. 2011, 2, 467. [CrossRef]

55. Xu, F.; Bao, J.; He, Q.; Park, Y.-J. Genome-wide association study of eating and cooking qualities in different subpopulations of rice (Oryza sativa L.). BMC Genom. 2016, 17, 663. [CrossRef]

56. Wang, Y.; Hou, Y.; Qiu, J.; Li, Z.; Zhao, J.; Tong, X.; Zhang, J. A Quantitative Acetylomic Analysis of Early Seed Development in Rice (Oryza sativa L.). Int. J. Mol. Sci. 2017, 18, 1376. [CrossRef] [PubMed]

57. Bao, J.; Zhou, X.; Xu, F.; He, Q.; Park, Y.J. Genome-wide association study of the resistant starch content in rice grains. Starch-Stärke 2017, 69, 1600343. [CrossRef] 
58. Chen, L.; Gao, W.; Chen, S.; Wang, L.; Zou, J.; Liu, Y.; Wang, H.; Chen, Z.; Guo, T. High-resolution QTL mapping for grain appearance traits and co-localization of chalkiness-associated differentially expressed candidate genes in rice. Rice 2016, 9, 48. [CrossRef] [PubMed]

59. Wang, Y.; Xiong, G.; Hu, J.; Jiang, L.; Yu, H.; Xu, J.; Fang, Y.; Zeng, L.; Xu, E.; Xu, J. Copy number variation at the GL7 locus contributes to grain size diversity in rice. Nat. Genet. 2015, 47, 944. [CrossRef] [PubMed]

60. Fan, C.; Xing, Y.; Mao, H.; Lu, T.; Han, B.; Xu, C.; Li, X.; Zhang, Q. GS3, a major QTL for grain length and weight and minor QTL for grain width and thickness in rice, encodes a putative transmembrane protein. Theor. Appl. Genet. 2006, 112, 1164-1171. [CrossRef] [PubMed]

61. Shomura, A.; Izawa, T.; Ebana, K.; Ebitani, T.; Kanegae, H.; Konishi, S.; Yano, M. Deletion in a gene associated with grain size increased yields during rice domestication. Nat. Genet. 2008, 40, 1023. [CrossRef] [PubMed]

62. Weng, J.; Gu, S.; Wan, X.; Gao, H.; Guo, T.; Su, N.; Lei, C.; Zhang, X.; Cheng, Z.; Guo, X. Isolation and initial characterization of GW5, a major QTL associated with rice grain width and weight. Cell Res. 2008, 18, 1199. [CrossRef]

63. Zhou, L.; Chen, L.; Jiang, L.; Zhang, W.; Liu, L.; Liu, X.; Zhao, Z.; Liu, S.; Zhang, L.; Wang, J. Fine mapping of the grain chalkiness QTL qPGWC-7 in rice (Oryza sativa L.). Theor. Appl. Genet. 2009, 118, 581-590. [CrossRef]

64. Zhang, J.; Zhang, H.; Botella, J.R.; Zhu, J.K. Generation of new glutinous rice by CRISPR/Cas9-targeted mutagenesis of the Waxy gene in elite rice varieties. J. Integr. Plant Biol. 2018, 60, 369-375. [CrossRef]

65. Sun, Y.; Jiao, G.; Liu, Z.; Zhang, X.; Li, J.; Guo, X.; Du, W.; Du, J.; Francis, F.; Zhao, Y. Generation of high-amylose rice through CRISPR/Cas9-mediated targeted mutagenesis of starch branching enzymes. Front. Plant Sci. 2017, 8, 298. [CrossRef]

66. Chao, S.; Cai, Y.; Feng, B.; Jiao, G.; Sheng, Z.; Luo, J.; Tang, S.; Wang, J.; Wei, X.; Hu, P. Editing of the rice isoamylase gene ISA1 provides insights into its function in starch formation. Rice Sci. 2019, 26, 2.

67. Shan, Q.; Wang, Y.; Li, J.; Gao, C. Genome editing in rice and wheat using the CRISPR/Cas system. Nat. Protoc. 2014, 9, 2395. [CrossRef] [PubMed]

68. Yang, Q.Q.; Zhang, C.Q.; Chan, M.L.; Zhao, D.S.; Chen, J.Z.; Wang, Q.; Li, Q.F.; Yu, H.X.; Gu, M.H.; Sun, S.S.M. Biofortification of rice with the essential amino acid lysine: Molecular characterization, nutritional evaluation, and field performance. J. Exp. Bot. 2016, 67, 4285-4296. [CrossRef] [PubMed]

69. Tang, L.; Mao, B.; Li, Y.; Lv, Q.; Zhang, L.; Chen, C.; He, H.; Wang, W.; Zeng, X.; Shao, Y. Knockout of OsNramp5 using the CRISPR/Cas9 system produces low Cd-accumulating indica rice without compromising yield. Sci. Rep. 2017, 7, 14438. [CrossRef] [PubMed]

70. Li, M.; Li, X.; Zhou, Z.; Wu, P.; Fang, M.; Pan, X.; Lin, Q.; Luo, W.; Wu, G.; Li, H. Reassessment of the four yield-related genes Gn1a, DEP1, GS3, and IPA1 in rice using a CRISPR/Cas9 system. Front. Plant Sci. 2016, 7, 377. [CrossRef] [PubMed]

71. Zhao, D.S.; Li, Q.F.; Zhang, C.Q.; Zhang, C.; Yang, Q.Q.; Pan, L.X.; Ren, X.Y.; Lu, J.; Gu, M.H.; Liu, Q.Q. GS9 acts as a transcriptional activator to regulate rice grain shape and appearance quality. Nat. Commun. 2018, 9 , 1240. [CrossRef] [PubMed]

72. Xu, R.; Yang, Y.; Qin, R.; Li, H.; Qiu, C.; Li, L.; Wei, P.; Yang, J. Rapid improvement of grain weight via highly efficient CRISPR/Cas9-mediated multiplex genome editing in rice. J. Genet. Genom. 2016, 43, 529-532. [CrossRef]

73. Zhou, H.; He, M.; Li, J.; Chen, L.; Huang, Z.; Zheng, S.; Zhu, L.; Ni, E.; Jiang, D.; Zhao, B. Development of commercial thermo-sensitive genic male sterile rice accelerates hybrid rice breeding using the CRISPR/Cas9-mediated TMS5 editing system. Sci. Rep. 2016, 6, 37395. [CrossRef]

74. Wang, F.; Wang, C.; Liu, P.; Lei, C.; Hao, W.; Gao, Y.; Liu, Y.-G.; Zhao, K. Enhanced rice blast resistance by CRISPR/Cas9-targeted mutagenesis of the ERF transcription factor gene OsERF922. PLoS ONE 2016, 11, e0154027. [CrossRef]

75. Zhou, X.; Liao, H.; Chern, M.; Yin, J.; Chen, Y.; Wang, J.; Zhu, X.; Chen, Z.; Yuan, C.; Zhao, W. Loss of function of a rice TPR-domain RNA-binding protein confers broad-spectrum disease resistance. Proc. Natl. Acad. Sci. USA 2018, 115, 3174-3179. [CrossRef]

76. Sun, Y.; Zhang, X.; Wu, C.; He, Y.; Ma, Y.; Hou, H.; Guo, X.; Du, W.; Zhao, Y.; Xia, L. Engineering herbicide-resistant rice plants through CRISPR/Cas9-mediated homologous recombination of acetolactate synthase. Mol. Plant 2016, 9, 628-631. [CrossRef] [PubMed] 
77. Shen, C.; Que, Z.; Xia, Y.; Tang, N.; Li, D.; He, R.; Cao, M. Knock out of the annexin gene OsAnn3 via CRISPR/Cas9-mediated genome editing decreased cold tolerance in rice. J. Plant Biol. 2017, 60, 539-547. [CrossRef]

78. Li, Y.; Fan, C.; Xing, Y.; Yun, P.; Luo, L.; Yan, B.; Peng, B.; Xie, W.; Wang, G.; Li, X. Chalk5 encodes a vacuolar $\mathrm{H}+$-translocating pyrophosphatase influencing grain chalkiness in rice. Nat. Genet. 2014, 46, 398. [CrossRef]

79. Shen, L.; Li, J.; Fu, Y.; Wang, J.; Hua, Y.; Jiao, X.; Yan, C.; Wang, K. Orientation improvement of grain length and grain number in rice by using CRISPR/Cas9 system. Chin. J. Rice Sci. 2017, 31, 223-231.

80. Takeuchi, Y.; Nonoue, Y.; Ebitani, T.; Suzuki, K.; Aoki, N.; Sato, H.; Ideta, O.; Hirabayashi, H.; Hirayama, M.; Ohta, H. QTL detection for eating quality including glossiness, stickiness, taste and hardness of cooked rice. Breed. Sci. 2007, 57, 231-242. [CrossRef]

81. Wang, Z.Y.; Zheng, F.Q.; Shen, G.Z.; Gao, J.P.; Snustad, D.P.; Li, M.G.; Zhang, J.L.; Hong, M.M. The amylose content in rice endosperm is related to the post-transcriptional regulation of the waxy gene. Plant J. 1995, 7 , 613-622. [CrossRef] [PubMed]

82. Zhang, G.; Cheng, Z.; Zhang, X.; Guo, X.; Su, N.; Jiang, L.; Mao, L.; Wan, J. Double repression of soluble starch synthase genes SSIIa and SSIIIa in rice (Oryza sativa L.) uncovers interactive effects on the physicochemical properties of starch. Genome 2011, 54, 448-459. [CrossRef]

83. Wu, Y.-P.; Pu, C.-H.; Lin, H.-Y.; Huang, H.-Y.; Huang, Y.-C.; Hong, C.-Y.; Chang, M.-C.; Lin, Y.-R. Three novel alleles of FLOURY ENDOSPERM2 (FLO2) confer dull grains with low amylose content in rice. Plant Sci. 2015, 233, 44-52. [CrossRef] [PubMed]

84. Zhang, K.; Raboanatahiry, N.; Zhu, B.; Li, M. Progress in genome editing technology and its application in plants. Front. Plant Sci. 2017, 8, 177. [CrossRef]

85. Wambugu, P.; Ndjiondjop, M.N.; Furtado, A.; Henry, R. Sequencing of bulks of segregants allows dissection of genetic control of amylose content in rice. Plant Biotechnol. J. 2018, 16, 100-110. [CrossRef]

86. Ma, X.; Zhang, Q.; Zhu, Q.; Liu, W.; Chen, Y.; Qiu, R.; Wang, B.; Yang, Z.; Li, H.; Lin, Y. A robust CRISPR/Cas9 system for convenient, high-efficiency multiplex genome editing in monocot and dicot plants. Mol. Plant 2015, 8, 1274-1284. [CrossRef] [PubMed]

87. Terada, R.; Nakajima, M.; Isshiki, M.; Okagaki, R.J.; Wessler, S.R.; Shimamoto, K. Antisense waxy genes with highly active promoters effectively suppress waxy gene expression in transgenic rice. Plant Cell Physiol. 2000, 41, 881-888. [CrossRef] [PubMed]

88. Shao, G.; Xie, L.; Jiao, G.; Wei, X.; Sheng, Z.; Tang, S.; Hu, P. CRISPR/CAS9-mediated editing of the fragrant gene Badh2 in rice. Chin. J. Rice Sci. 2017, 31, 216-222.

89. Nordin, Y.; Lantbruksakademien, K.S.O. Golden Rice and Other Biofortified Food Crops for Developing Countries: Challenges and Potential; FAO: Rome, Italy, 2008.

90. Potrykus, I. Golden Rice from idea to reality. Bertebos Prize lecture. In Proceedings of the Bertebos Conference, Falkenberg, Sweden, 7-9 September 2008; pp. 11-16.

91. Wenefrida, I.; Utomo, H.S.; Blanche, S.B.; Linscombe, S.D. Enhancing essential amino acids and health benefit components in grain crops for improved nutritional values. Recent Adv. DNA Gene Seq. 2009, 3, $219-225$. [CrossRef]

92. Shewry, P.R.; Halford, N.G. Cereal seed storage proteins: Structures, properties and role in grain utilization. J. Exp. Bot. 2002, 53, 947-958. [CrossRef] [PubMed]

93. Liu, X.; Zhang, C.; Wang, X.; Liu, Q.; Yuan, D.; Pan, G.; Sun, S.S.; Tu, J. Development of high-lysine rice via endosperm-specific expression of a foreign LYSINE RICH PROTEIN gene. BMC Plant Biol. 2016, 16, 147. [CrossRef] [PubMed]

94. Kawakatsu, T.; Hirose, S.; Yasuda, H.; Takaiwa, F. Reducing rice seed storage protein accumulation leads to changes in nutrient quality and storage organelle formation. Plant Physiol. 2010, 154, 1842-1854. [CrossRef]

95. Liu, J.; Wu, X.; Yao, X.; Yu, R.; Larkin, P.J.; Liu, C.-M. Mutations in the DNA demethylase OsROS1 result in a thickened aleurone and improved nutritional value in rice grains. Proc. Natl. Acad. Sci. USA 2018, 115, 11327-11332. [CrossRef]

96. Xu, M.; Zhao, S.; Zhang, Y.; Yin, H.; Peng, X.; Cheng, Z.; Yang, Z.; Zheng, J. Production of Marker-free Transgenic Rice (Oryza sativa L.) with Improved Nutritive Quality Expressing AmA1. Iran. J. Biotechnol. 2017, 15, 102. [CrossRef] 
97. Jiang, S.Y.; Ma, A.; Xie, L.; Ramachandran, S. Improving protein content and quality by over-expressing artificially synthetic fusion proteins with high lysine and threonine constituent in rice plants. Sci. Rep. 2016, 6, 34427. [CrossRef]

98. Wada, Y.; Ujiie, A.; Carsono, N.; Yoshida, T. Bread making characteristics of the whole grain flour made from wheat Glu-1Dx5 gene transferred rice. Jpn. J. Crop Sci. 2010, 79, 26-28. [CrossRef]

99. Lee, T.T.; Leu, W.M.; Yang, H.H.; Chen, B.C.; Tzen, J.T. Sesame oleosin and prepro-2S albumin expressed as a fusion polypeptide in transgenic rice were split, processed and separately assembled into oil bodies and protein bodies. J. Cereal Sci. 2006, 44, 333-341. [CrossRef]

100. Chen, P.; Shen, Z.; Ming, L.; Li, Y.; Dan, W.; Lou, G.; Peng, B.; Wu, B.; Li, Y.; Zhao, D. Genetic Basis of Variation in Rice Seed Storage Protein (Albumin, Globulin, Prolamin, and Glutelin) Content Revealed by Genome-Wide Association Analysis. Front. Plant Sci. 2018, 9, 612. [CrossRef] [PubMed]

101. Ren, Y.; Wang, Y.; Liu, F.; Zhou, K.; Ding, Y.; Zhou, F.; Wang, Y.; Liu, K.; Gan, L.; Ma, W. GLUTELIN PRECURSOR ACCUMULATION3 encodes a regulator of post-Golgi vesicular traffic essential for vacuolar protein sorting in rice endosperm. Plant Cell 2014, 26, 410-425. [CrossRef] [PubMed]

102. Lucca, P.; Hurrell, R.; Potrykus, I. Genetic engineering approaches to improve the bioavailability and the level of iron in rice grains. Theor. Appl. Genet. 2001, 102, 392-397. [CrossRef]

103. Vasconcelos, M.; Datta, K.; Oliva, N.; Khalekuzzaman, M.; Torrizo, L.; Krishnan, S.; Oliveira, M.; Goto, F.; Datta, S.K. Enhanced iron and zinc accumulation in transgenic rice with the ferritin gene. Plant Sci. 2003, 164, 371-378. [CrossRef]

104. Khalekuzzaman, M.; Datta, K.; Oliva, N.; Alam, M.; Datta, S. Stable integration, expression and inheritance of the ferritin gene in transgenic elite indica rice cultivar BR29 with enhanced iron level in the endosperm. Indian J. Biotechnol. 2006, 5, 26-31.

105. Kobayashi, T.; Nishizawa, N.K. Iron uptake, translocation, and regulation in higher plants. Annu. Rev. Plant Biol. 2012, 63, 131-152. [CrossRef]

106. Lee, S.; Jeon, J.S.; An, G. Iron homeostasis and fortification in rice. J. Plant Biol. 2012, 55, 261-267. [CrossRef]

107. Bashir, K.; Takahashi, R.; Nakanishi, H.; Nishizawa, N.K. The road to micronutrient biofortification of rice: Progress and prospects. Front. Plant Sci. 2013, 4, 15. [CrossRef]

108. Zheng, L.; Cheng, Z.; Ai, C.; Jiang, X.; Bei, X.; Zheng, Y.; Glahn, R.P.; Welch, R.M.; Miller, D.D.; Lei, X.G. Nicotianamine, a novel enhancer of rice iron bioavailability to humans. PLoS ONE 2010, 5, e10190. [CrossRef] [PubMed]

109. Johnson, A.A.; Kyriacou, B.; Callahan, D.L.; Carruthers, L.; Stangoulis, J.; Lombi, E.; Tester, M. Constitutive overexpression of the OsNAS gene family reveals single-gene strategies for effective iron-and zinc-biofortification of rice endosperm. PLOS ONE 2011, 6, e24476. [CrossRef] [PubMed]

110. Paine, J.A.; Shipton, C.A.; Chaggar, S.; Howells, R.M.; Kennedy, M.J.; Vernon, G.; Wright, S.Y.; Hinchliffe, E.; Adams, J.L.; Silverstone, A.L.; et al. Improving the nutritional value of Golden Rice through increased pro-vitamin A content. Nat. Biotechnol. 2005, 23, 482. [CrossRef] [PubMed]

111. Yang, X.; Chen, L.; Yu, W. Knocking out of carotenoid catabolic genes in rice fails to boost carotenoid accumulation, but reveals a mutation in strigolactone biosynthesis. Plant Cell Rep. 2017, 36, 1533-1545. [CrossRef] [PubMed]

112. Xie, K.; Minkenberg, B.; Yang, Y. Boosting CRISPR/Cas9 multiplex editing capability with the endogenous tRNA-processing system. Proc. Natl. Acad. Sci. USA 2015, 112, 3570-3575. [CrossRef] [PubMed]

113. Liang, G.; Huimin, Z.; Dengji, L.; Diqiu, Y. Selection of highly efficient sgRNAs for CRISPR/Cas9-based plant genome editing. Sci. Rep. 2016, 6, 21451. [CrossRef]

114. Shen, L.; Wang, C.; Fu, Y.; Wang, J.; Liu, Q.; Zhang, X.; Yan, C.; Qian, Q.; Wang, K. QTL editing confers opposing yield performance in different rice varieties. J. Integr. Plant Biol. 2018, 60, 89-93. [CrossRef]

115. Zhou, H.; Liu, B.; Weeks, D.P.; Spalding, M.H.; Yang, B. Large chromosomal deletions and heritable small genetic changes induced by CRISPR/Cas9 in rice. Nucleic Acids Res. 2014, 42, 10903-10914. [CrossRef]

116. Barman, H.N.; Sheng, Z.; Fiaz, S.; Zhong, M.; Wu, Y.; Cai, Y.; Wang, W.; Jiao, G.; Tang, S.; Wei, X.; et al. Generation of Thermo-sensitive Genic Sterile Line by Knockout TMS5 Gene based on CRISPR/Cas9 System. BMC Plant Biol. 2019, accepted.

117. Li, Z. Health risk characterization of maximum legal exposures for persistent organic pollutant (POP) pesticides in residential soil: An analysis. J. Environ. Manag. 2018, 205, 163-173. [CrossRef] 
118. Xu, R.; Li, H.; Qin, R.; Wang, L.; Li, L.; Wei, P.; Yang, J. Gene targeting using the Agrobacterium tumefaciens-mediated CRISPR-Cas system in rice. Rice 2014, 7, 5. [CrossRef] [PubMed]

119. Wang, X.; Fan, J.; Xing, Y.; Xu, G.; Wang, H.; Deng, J.; Wang, Y.; Zhang, F.; Li, P.; Li, Z. The Effects of Mulch and Nitrogen Fertilizer on the Soil Environment of Crop Plants. Adv. Agron. 2019, 153, 121-173.

(C) 2019 by the authors. Licensee MDPI, Basel, Switzerland. This article is an open access article distributed under the terms and conditions of the Creative Commons Attribution (CC BY) license (http:/ / creativecommons.org/licenses/by/4.0/). 